\title{
Responses of Chaparral and Oak Woodland Plant Communities to Fuel-Reduction Thinning in Southwestern Oregon
}

\author{
Keith A. Perchemlides, ${ }^{1}$ Patricia S. Muir, ${ }^{2}$ and Paul E. Hosten ${ }^{3}$ \\ Authors are ${ }^{1}$ Biological Science Technician, USDA Forest Service, Sierra Nevada Research Center, Davis, CA 95616, USA; ${ }^{2}$ Professor, Department of \\ Botany and Plant Pathology, Oregon State University, Corvallis, OR 97331, USA; and ${ }^{3}$ Ecologist, Bureau of Land Management, Medford District, \\ Medford, OR 97504, USA.
}

\begin{abstract}
Fire suppression has led to large fuel accumulations in many regions of the United States. In response to concerns about associated wildfire hazards, land managers in the western United States are carrying out extensive fuel-reduction thinning programs. Although reductions in cover by woody vegetation seem likely to cause changes in herbaceous communities, few published studies have reported on consequences of such treatments for native or exotic plant species. We compared vegetation and abiotic characteristics between paired thinned and unthinned chaparral and oak woodland communities of southwestern Oregon 4-7 yr posttreatment and contrasted impacts of manual vs. mechanical treatments. Herbaceous cover increased on thinned sites, but species richness did not change. Herbaceous communities at thinned sites had an early postdisturbance type of composition dominated by native annual forbs and exotic annual grasses; cover by annuals was nearly twice as high on treated as on untreated sites. Absolute and proportional cover of native annual forbs increased more than any other trait group, whereas exotic annual forbs and native perennial forbs declined. Exotic annual grass cover (absolute and proportional) increased, whereas cover by native perennial grasses did not. Shrub reestablishment was sparse after thinning, probably because of a lack of fire-stimulated germination. Manual and mechanical treatment impacts on abiotic site conditions differed, but differences in vegetation impacts were not statistically significant. Fuel-reduction thinning may have some unintended negative impacts, including expansion of exotic grasses, reductions in native perennial species cover, persistent domination by annuals, and increased surface fuels. Coupled with sparse tree or shrub regeneration, these alterations suggest that ecological-state changes may occur in treated communities. Such changes might be mitigated by retaining more woody cover than is currently retained, seeding with native perennials after treatment, or other practices; further research is needed to inform management in these ecosystems.
\end{abstract}

\section{Resumen}

En muchas regiones de Estados Unidos, la supresión del fuego ha provocado grandes acumulaciones de combustible. En repuesta a las preocupaciones respecto a los peligros asociados a los fuegos no controlados, los manejadores de tierras del oeste de Estados Unidos están conduciendo programas extensivos de aclareo para reducir el combustible. Mientras que la reducción de cobertura de la vegetación leñosa parece que probablemente cause cambios en las comunidades herbáceas, pocos estudios publicados han reportado las consecuencias de tales tratamientos en las especies nativas o exóticas. Comparamos características de vegetación y abióticas entre comunidades apareadas de "Chaparral" y "Oak" con y sin aclareo en el sudoeste de Oregon 4 y 7 años después de aplicar los tratamientos, y contrastamos los impactos de tratamientos manuales contra mecánicos. La cobertura herbácea se incrementó en los sitios con aclareo, pero la riqueza de especies no cambio. Las comunidades herbáceas en los sitios con aclareo tenían un tipo de composición similar al de la etapa inicial postdisturbio, dominada por hierbas nativas anuales y zacates anuales exóticos, la cobertura de anuales en los sitios tratados fue casi el doble de la de sitios no tratados. La cobertura absoluta y proporcional de las hierbas anuales nativas se incrementó más que cualquier otra característica del grupo, mientras que la de hierbas anuales exóticas y hierbas nativas perennes disminuyó. La cobertura (absoluta y proporcional) de zacates anuales exóticos aumentó, en tanto que la de zacates perennes nativos no. El reestablecimiento de arbustos después del aclareo fue escaso y la distancia entre individuos fue amplia, probablemente debido a la falta de germinación estimulada por fuego. Los impactos de los tratamientos manuales y mecánicos sobre las condiciones abióticas del sitio difirieron, pero las diferencias en los impactos sobre la vegetación no fueron estadísticamente significativas. La reducción de combustible por aclareo puede tener algunos impactos negativos no intencionados, incluyendo la expansión de zacates exóticos, reducciones de la cobertura de especies nativas perennes, el dominio persistente de especies anuales y un aumento de combustibles en la superficie. En conjunto con la escasa regeneración de árboles y arbustos, estas alteraciones sugieren que pueden ocurrir cambios en el estado ecológico de las comunidades tratadas. Tales cambios pudieran ser mitigados dejando más cobertura de vegetación leñosa de la que actualmente se deja, sembrando especies nativas perennes después del tratamiento u otras prácticas. Se requiere más investigación para documentar el manejo de manejo de estos ecosistemas.

Key Words: Arctostaphylos, Ceanothus, exotic annual grasses, mastication

Research was funded by the Joint Fire Science Program; Dept of Botany and Plant Pathology, Oregon State University; and the Bureau of Land Management, Medford District. At the time of research, Perchemlides was a graduate research assistant, Dept of Botany and Plant Pathology, Oregon State University, Corvallis, OR 97331, USA. Correspondence: Dr Patricia Muir, Dept of Botany and Plant Pathology, Oregon State University, Corvallis, OR 97331-2902, USA. Email: muirp@science.oregonstate.edu

Manuscript received 19 March 2007; manuscript accepted 16 October 2007. 


\section{INTRODUCTION}

Decades of fire suppression and other human influences have changed vegetation structure and composition in many western ecosystems (Covington and Moore 1994; Heyerdahl et al. 2001; Taylor and Skinner 2003; Odion et al. 2004; Miller et al. 2005). Augmented stand densities and biomass accumulations can increase the risk that high-severity, stand-replacing fires will occur (e.g., Minnich 1983; Agee 1993, 1998; Covington et al. 1997; Office of the President 2002). Fire exclusion can also cause changes in community composition and decreases in habitat diversity because species that rely on fire to persist are replaced by those more competitive in the absence of fire (Kauffman and Martin 1987; Reed and Sugihara 1987; Swetnam et al. 1999; Franklin et al. 2004; Miller et al. 2005). Ecosystem changes are aggravated by exotic invasive plants, which often invade or expand following disturbances, displacing native vegetation and sometimes altering fire regimes (Hobbs and Huenneke 1992; Pyke 1999; Sheley and Petroff 1999; Brooks et al. 2004). Residential expansion into wildlands exacerbates these concerns by elevating risks to human life and property from wildfire (Dombeck et al. 2004), augmenting ignitions and increasing fire occurrence (Keeley et al. 1999), and facilitating the spread of invasive plants (Sheley and Petroff 1999; Gelbard and Belnap 2002; Fried et al. 2004).

In response to concerns about high-severity wildfires, land managers in the western United States are carrying out largescale fuel-reduction thinning programs (US Department of Agriculture 2000). In some cases, fuel-reduction programs are simultaneously intended to facilitate restoration of ecosystems that are known or assumed to have been altered by fire suppression (e.g., US Department of the Interior [USDI] 1999). Although some fuel-reduction methods include prescribed fire, others do not, largely because of concerns about fire hazard or smoke impacts in wildland-urban interface areas. We do not know whether ecosystem consequences of "fire surrogate" fuelreduction methods mimic those associated with fire, particularly in fire-dependent ecosystems.

For example, chaparral species characteristically have traits that both allow persistence after fire and create a dependence on fire for regeneration and renewal of habitat (Keeley and Zedler 1978; Keeley et al. 1981; Odion and Davis 2000; Fried et al. 2004). Fire-associated cues stimulate germination for many shrub and forb species associated with chaparral systems, whereas others sprout vigorously after fire (Keeley et al. 1985; Keeley 1987; Keeley and Fotheringham 1998; Borchert 1989). How will fire-adapted or other native species respond to fuelreduction thinning treatments in which fire is absent or dramatically different from wildfire? Further, in fire-dependent ecosystems from which fire has been excluded, the absence of fire and lack of suitable habitat beneath dense canopies may have depleted native species' seed banks (Borchert 1989), limiting their capacity to reestablish in thinned sites. By contrast, invasive exotic species often colonize disturbed sites rapidly, especially when present before disturbance (Hobbs and Huenneke 1992; Sheley and Petroff 1999; Davis et al. 2000). Exotic species' abundance increased markedly in artificially created fuel breaks in California, and those species then expanded rapidly into adjacent, untreated areas (Merriam et al. 2006). Is expansion of exotic species following fuel- reduction treatments a widespread phenomenon? Will a history of fire suppression plus the disturbances associated with thinning treatments allow such species to overtake thinned sites? What will be the relatively long-term effects of those treatments on plant communities and canopy-species regeneration? Where thinning treatments have both fuel-reduction and ecological restoration objectives, to what extent are those goals compatible?

To seek answers to these questions, we sampled vegetation and abiotic site characteristics along paired transects in thinned and unthinned chaparral and oak woodland communities of southwestern Oregon. Transects were established retrospectively at sites that were thinned for fuel reduction 4-7 yr before sampling. The Medford District Bureau of Land Management (BLM) began a fuel-reduction thinning program in this area in the mid-1990s, treating thousands of hectares per year across the variety of ecosystems present on BLM lands (USDI 2002). In the chaparral and oak woodland communities we studied, treatments were mechanical or manual. Mechanical mastication (MM) used heavy equipment referred to as a Slashbuster, which fragments trees and shrubs to the stump and leaves woody debris scattered on the ground. In manual treatments, called hand-cut and pile-burn (HPB), woody vegetation was chainsaw-cut and piled, with piles then burned during late fall or winter. In both treatments, tree and shrub cover was reduced by approximately $70 \%$, woody stem densities were reduced by approximately $90 \%$, and shrubs and small-diameter trees were targeted for thinning.

In addition to reducing canopy cover, these treatments affect the ground surface, potentially affecting its suitability for plant establishment or growth. Bare soil patches and changes in litter cover influence the suitability of sites for seed germination and seedling survival and also affect soil moisture and erosion (Keeley 1992; Whisenant 1999). Pile-burning following manual thinning can cause severe soil heating that leaves persistent burn scars that may favor establishment of opportunistic or invasive species (Dickinson and Kirkpatrick 1987; Korb et al. 2004; Sikes 2005). Wood debris from mechanical mastication can cover much of the soil surface, potentially acting as a physical barrier to seed germination and herbaceous growth but also modifying microclimatic conditions in ways that might benefit plant establishment. We analyzed whether mechanical mastication and HPB treatments differ in impacts on herbaceous communities and regeneration of woody species. Whereas one previous study examined short-term (1-2 yr) consequences of these treatments for plant communities in chaparral systems near our study area (Sikes 2005), no published studies to date have described longer-term impacts despite the landscape scale at which treatments have been applied.

\section{METHODS}

\section{Study Area}

Field research was conducted on USDI BLM lands (Medford District, Ashland Resource Area) within the Applegate River watershed of the Rogue River drainage in southwestern Oregon (lat $42^{\circ} \mathrm{N}$, long $122^{\circ} \mathrm{W}$ ). The valleys and foothills of the Applegate River watershed have a Mediterranean-type climate of cool, wet winters and hot, dry summers. Average annual 
precipitation for the centrally located town of Ruch, Oregon, is $644 \mathrm{~mm}$, mostly falling as rain from November through April. Average January low temperature is $-1.0^{\circ} \mathrm{C}$, and the average July maximum is $32.3^{\circ} \mathrm{C}$ (Western Regional Climate Center 2006). At lower elevations and on southerly aspects, conditions are xeric, and vegetation is characterized by mosaics of oak woodlands, shrub/chaparral, and open grasslands (Franklin and Dyrness 1973).

Ceanothus cuneatus (Hook.) Nutt., Arctostaphylos viscida Parry, and Quercus garryana Dougl. ex Hook. mix with each other and, to a lesser degree, with Quercus kelloggii Newb., Pinus ponderosa Laws., Arbutus menziesii Pursh., and Pseudotsuga menziesii (Mirbel) Franco. in these chaparral and oak woodland communities (Detling 1961; plant nomenclature follows Hickman 1993). For the drier south-facing slopes, on which this study focuses, native grasses are primarily perennial bunchgrasses, including Achnatherum lemmonii (Vasey) Barkworth and species of Bromus, Elymus, and Festuca. Nonnative invasive annual grasses are widespread, including Avena fatua L., Bromus tectorum L. and other Bromus spp., Taeniatherum caput-medusae (L.) Nevski, and Cynosurus echinatus L. (Pyke 1999; Whitson et al. 2004). Weedy, nonnative forbs of concern include Centaurea solstitialis L., Hypericum perforatum L., and Torilis arvensis (Huds.) Link (Pyke 1999; Sheley and Petroff 1999). Annual and perennial native forbs are abundant; Madia, Clarkia, and Lomatium species are common, as are members of the Boraginaceae, Fabaceae, Liliaceae, and Asteraceae (Perchemlides 2006)

The area's disturbance history includes grazing, small-scale mining, logging, soil scarification, conifer plantings, fuel-wood harvesting, off-highway vehicle (OHV) use, wildfire, and intentional use of fire by settlers and Native Americans (Agee 1993; USDI 1999; Hosten et al. 2006). Expansion of residential development into rural areas and a checkerboard-like pattern of interspersed public and private lands led to the designation of $>55600$ ha of Medford District BLM lands as Rural Interface Areas by 2001 (USDI 2002). These ownership patterns, combined with recent wildfires, have heightened concerns about fire risks, leading to large-scale application of fuel-reduction thinning treatments beginning in the mid-1990s (USDI 1999; Coogle 2002). Our study was conducted in some of the $>2000$ ha of chaparral and mixed-oak vegetation treated for fuel reduction between 1996 and 2001 in the Ashland Resource Area (USDI 2002). On some sites, treatment objectives included both fuel reduction and restoration of native plant communities, whereas on other sites, especially in chaparral, management was largely focused on reducing fuels.

\section{Field Methods}

Sampling occurred in sites representative of the area's mixed chaparral and oak woodland communities. Selected sites had canopies dominated by varying mixtures of Arctostaphylos viscida, Ceanothus cuneatus, and Quercus garryana. Sites were field-assigned into one of three canopy vegetation groups: 1) A. viscida-dominated chaparral, 2) C. cuneatus-dominated chaparral, or 3 ) mixed Q. garryana and shrub with both shrub species well-represented among scattered oaks. Elevations ranged from approximately 500 to $1000 \mathrm{~m}$, aspects ranged from $105^{\circ}$ to $275^{\circ}$, and slopes were between $10^{\circ}$ and $35^{\circ}$. All sites were sampled during June and July 2005. Sampled sites had been thinned for fuel reduction between May 1998 and June 2001.

No detailed pretreatment vegetation data were available; hence, this study was retrospective and based on comparisons between paired treated and untreated transects. Although we use the phrase treatment effects to refer to differences between these pairs, the retrospective and observational nature of this study makes it impossible to determine cause and effect with certainty. Field-matching of transects was based on within-pair similarity in canopy species structure and composition (relying on information derived from stumps and leave-trees in thinned areas); slope and aspect; landscape features; and proximity to roads or OHV tracks. Potential sites were identified using a geographic information system (GIS) fuels-treatment-unitspatial database (USDI 2005). GIS data were combined with digitized aerial photographs using ArcMap software (ArcMap GIS, Version 8.3; ESRI Inc, Redlands, CA) to identify potentially suitable units. Paired transects were established based on the presence of acceptably matched treated and untreated areas of vegetation of $\geq 1800 \mathrm{~m}^{2}$ each, and an absence of recent disturbances other than fuel-reduction thinning. We sampled 30 transect pairs, with only one pair of transects established per canopy vegetation community in a given treatment unit. Canopy cover on sampled sites ranged between $40 \%$ and $93 \%$ for untreated sites with a mean of $70 \%$, and from $1.5 \%$ to $61 \%$ (mean of $29 \%$ ) at treated sites (Perchemlides 2006).

We located $50-\mathrm{m}$ transects $\geq 10 \mathrm{~m}$ from treatment edges or natural boundaries. Paired treated and untreated transects followed similar bearings $\left( \pm 20^{\circ}\right)$ and were generally $\leq 50 \mathrm{~m}$ apart. We sampled sites from lower to higher elevations to minimize phenological variation. Five $3-\mathrm{m}^{2}$ canopy-measurement plots per transect were located by constrained randomization, such that one circle fell within each of the five consecutive $10-\mathrm{m}$ transect intervals. Within each canopy plot, we recorded cover classes for all woody species and stem counts for nonvining woody species. Cover classes approximated an arcsine square root transformation (Muir and McCune 1987): 0 (none), 1 (<1\%), 2 (1\%-5\%), 3 (5\%-25\%), 4 (25\%-50\%), $5(50 \%-75 \%), 6(75 \%-95 \%), 7(95 \%-99 \%)$, and $8(>99 \%)$. We recorded height $(<0.3 \mathrm{~m}, 0.3-1 \mathrm{~m}, 1-2 \mathrm{~m}, 2-3 \mathrm{~m}$, and $>3 \mathrm{~m}$ ) and condition class (dead, stump, or resprouting stump) for each individual. Cover percentage by burn-pile scars and unburned piles was also recorded. Densiometer readings of the percentage of canopy cover were taken $1 \mathrm{~m}$ above the ground at the center of each plot.

One $1000-\mathrm{cm}^{2}$ herbaceous cover plot was nested within each of two different randomly assigned quadrants of each canopy plot $\left(n=10\right.$ plots $\cdot$ transect $\left.^{-1}\right)$. Within these plots, we recorded percentage of cover, as above, by species for all grasses and forbs and for woody vegetation $<0.3 \mathrm{~m}$ tall, including tree and shrub seedlings (hereafter collectively referred to as herbaceous vegetation). We also recorded cover classes for litter, bare soil, and down wood as fuel-hour based diameter categories $(<1 \mathrm{~cm}, 1-3 \mathrm{~cm}, 3-10 \mathrm{~cm}$, and $>10 \mathrm{~cm})$ in these plots.

\section{Analysis Methods}

Cover classes were converted to percentage of cover as the arithmetic midpoints of the cover-class intervals. Data collected 
in multiple plots within a transect were averaged. Data on species cover and abiotic variables often did not meet parametric assumptions, so we used nonparametric statistical tools for multivariate analyses (PC-ORD, Version 5.35 beta; MJM Software Design, Gleneden Beach, OR; McCune and Mefford 1999; McCune and Grace 2002) and univariate tests (S-PLUS, Version 7.0; Insightful Corp, Seattle, WA). We deleted species that occurred in fewer than $5 \%$ of transects (McCune and Grace 2002); the resultant community matrix contained percentage cover data for 95 species in 60 transects.

Data analysis was at the transect level and also used data expressed as differences between paired transects (treated minus untreated transect). Within-pair differences are presumed to indicate treatment responses within the limits of the retrospective study. All species are effectively given equal weight using difference data, which focuses analysis on changes in species composition regardless of each species' absolute abundance. Cover and stem count data were $\log _{10}$ transformed before subtraction; within-pair differences then represented the order-of-magnitude change for each species relative to its total abundance within the pair. We made matrices of within-pair differences in species composition and environmental variables.

All herbaceous species were categorized as native or exotic, annual or perennial (following Hickman 1993), and then placed into trait groups: native annual forbs, native perennial forbs, exotic annual forbs, exotic annual grasses, and native perennial grasses (see Perchemlides 2006 for a list of species by trait group). All tree and shrub species were native. For each transect, we summed percentage of cover from all herbaceous species and for all species within each category or trait group to yield summary measures of cover by category and group. Trait group and category cover values were divided by total herbaceous cover to calculate proportional measures of trait group or category dominance for each transect. Species richness and the Shannon-Weiner diversity index were calculated for each transect, and for native species within each transect (retaining data for species that occurred in fewer than $5 \%$ of transects).

Average percentage of canopy cover values from the canopy plots were summed across all woody species $\geq 0.3 \mathrm{~m}$ tall to give an herbaceous-layer perspective of canopy cover appropriate to the low canopies of shrubs. Transect averages for densiometer-based percentage canopy cover readings provided a larger-scale and more traditional measure of canopy cover. We summed average stem counts across woody species for size classes $>1 \mathrm{~m}$ tall to estimate densities per transect. Average stem counts for seedlings, resprouting stumps, and plants $<1 \mathrm{~m}$ tall were summed separately for tree and shrub species as measures of canopy species regeneration (a resprouting stump $=1$ stem). Percentage cover of downed wood was summed across size classes $>1 \mathrm{~cm}$ in diameter (wood debris) for each transect.

To address the basic question, "Was there a treatment effect?" we used a blocked version of multiple-response permutation procedure (MRBP; Euclidean distance) to compare herbaceous communities between treated and untreated transects blocked as pairs. Multiple-response permutation procedure (MRPP) is a nonparametric test for multivariate difference between two or more predefined groups (Zimmerman et al. 1985). MRPP and MRBP give both a $P$ value based on randomized group reassignments and an $A$ value measure of within-group homogeneity; when $A=1$, all items are identical within groups, and when $A=0$, homogeneity within groups is the same as expected by chance (McCune and Grace 2002). Three data transformations were used, each emphasizing a different perspective. With raw data, MRBP was most influenced by differences between transects in percentage of cover by the most abundant species and total cover. With $\log _{10}$-transformed data, additional weight is given to lessabundant species and MRBP comparisons were less affected by dominant species and differences in total cover, compared with those based on raw data. MRBP on data relativized by transect totals (McCune and Grace 2002) clarified the extent to which treated and untreated sites differed in species composition by removing the influence of differences among transects in total cover.

MRBP tests indicated whether there are differences between treated and untreated communities but did not identify which components differed. We assessed differences in specific abiotic and vegetation variables between treated and untreated transects using Wilcoxon sign-rank tests on within-pair difference data.

We also tested whether treatment effects differed between canopy vegetation groups $(n=10$ A. viscida-dominated; $n=11$ mixed $Q$. garryana and shrub; and $n=9$ C. cuneatusdominated pairs) or treatment types $(n=12 \mathrm{HPB}$; and $n=18$ MM pairs). Before doing so, we established whether their plant communities differed in the absence of treatments using MRPP (Sørensen distance) on both raw and $\log _{10}$-transformed cover data for untreated transects grouped by treatment type and by canopy vegetation type. To assess multivariate differences in treatment effects between treatment types and among canopy vegetation groups, we used MRPP (with Euclidean distances because some values were negative) on herbaceous within-pair difference data (treated minus untreated). Differences in individual vegetation and abiotic variables between treatment types were tested using Wilcoxon rank-sum tests on within-pair difference data.

\section{RESULTS}

A total of 126 herbaceous species were recorded across all transects; 101 were native, 25 were exotic (Perchemlides 2006), and 95 occurred in at least $5 \%$ of transects. Whittaker's $\beta$ diversity (McCune and Grace 2002) was 3.4, with mean species richness $(S)$ per transect of 28.6, and mean Shannon-Weiner $\left(H^{\prime}\right)$ diversity per transect of 2.59. Species richness and Shannon-Weiner diversity were essentially the same for treated and untreated areas $\left(S=112\right.$ and $111, H^{\prime}=2.56$ and 2.62, respectively). At untreated sites, herbaceous cover varied from $24 \%$ to $126 \%($ mean $=69 \%)$, compared with a range of $45 \%-$ $168 \%($ mean $=103 \%)$ for treated sites.

Herbaceous species composition differed among untreated canopy vegetation groups $(P<0.05$ from MRPP on untreated transect data), except for between $A$. viscida-dominated and mixed Q. garryana and shrub types, with raw data (Table 1). Pretreatment canopy cover was variable within each canopy vegetation type and tended to be lowest in C. cuneatusdominated chaparral (mean densitometer-based canopy cover 
Table 1. Multiple-response permutation procedure (MRPP) tests of herbaceous composition differences between untreated transects grouped by canopy vegetation or treatment type. Results are given for tests based on both raw and $\log _{10}$-transformed herbaceous cover data (see Analysis Methods). Boldface text highlights significant differences $(P<0.05)$ and corresponding $A$ values of within-group homogeneity. Treatment types: MM indicates mechanical mastication; HPB, hand-cut and pile-burn. Canopy vegetation groups: ARC indicates Arctostaphylos viscida-dominated; CEA, Ceanothus cuneatus-dominated; and MIX, mixed Quercus spp. and shrubs.

\begin{tabular}{|c|c|c|c|c|c|}
\hline \multirow[b]{2}{*}{ Group comparison } & \multirow[b]{2}{*}{ Transects $\cdot$ group $^{-1}$} & \multicolumn{2}{|c|}{ MRPP on raw data } & \multicolumn{2}{|c|}{ MRPP on $\log _{10}$ data } \\
\hline & & $P$ & $A$ & $P$ & $A$ \\
\hline HPB to MM & 12,18 & 0.282 & 0.003 & 0.073 & 0.011 \\
\hline ARC to MIX to CEA & $10,11,9$ & 0.000 & 0.048 & 0.000 & 0.068 \\
\hline ARC to CEA & 10,9 & 0.000 & 0.054 & 0.000 & 0.085 \\
\hline ARC to MIX & 10,11 & 0.080 & 0.015 & 0.011 & 0.030 \\
\hline CEA to MIX & 9,11 & 0.002 & 0.043 & 0.001 & 0.047 \\
\hline
\end{tabular}

estimates for woody species $>1 \mathrm{~m}$ tall were $81 \%, 56 \%$, and $71 \%$ for the A. viscida-dominated, C. cuneatus-dominated, and mixed Q. garryana and shrub groups, respectively; cover by woody species $\geq 0.3 \mathrm{~m}$ tall averaged $99 \%, 91 \%$, and $98 \%$ for the three groups, respectively). Herbaceous community composition did not differ significantly between untreated transects grouped as $\mathrm{HPB}$ or $\mathrm{MM}$ (minimum $P>0.07$; Table 1).

\section{Overall Treatment Effect-Treated vs. Untreated Sites}

Site conditions on treated transects differed (Wilcoxon signrank, $P<0.05$ ) from those on untreated transects, with most differences attributable to treatments. Mean cover by woody species $\geq 0.3 \mathrm{~m}$ tall was $71 \%$ lower (range $=0.1 \%-125 \%$ ) on treated than on untreated sites. Mean density for trees and shrubs $>1 \mathrm{~m}$ tall was 3.3 stems $\cdot 100 \mathrm{~m}^{-2}$ in treated areas, compared with 40 stems $100 \mathrm{~m}^{-2}$ in untreated areas. Wood debris cover averaged $>11 \%$ more across all treated sites, and $>16 \%$ more at MM treated sites (range $=5 \%-29 \%$ ) than at untreated sites. Burn-pile scars covered an average of $17 \%$ of the ground surface at HPB-treated sites (range $=0 \%-40 \%$ ), and mean cover by unburned piles at these sites was an additional $\sim 6 \%$ (range $=0 \%-28 \%$ ). Mean cover by litter and bare soil was $7 \%$ and $9 \%$ lower, respectively, on treated compared with untreated sites across treatment types (Table 2).

Herbaceous communities differed between treated and untreated transects across all pairs, whether tests were based on raw data or data relativized by transect totals (MRBP, all $P<0.001 ; A$ values $=0.159$ and 0.152 for raw data and data relativized by transect totals, respectively), indicating that differences were due to changes in species composition, not simply to a general increase in cover. Communities also differed when data were $\log _{10}$-transformed to increase weighting of less-abundant species, but the within-group similarity ( $A$ value) declined almost threefold $(P<0.001 ; A=0.056)$.

Single-variable tests showed clear differences in plant cover and composition between treated and untreated transects (Table 2). Because multiple comparisons were made within the same data set, probabilities from these tests should be interpreted with caution. Means for total herbaceous cover and cover of native and annual species, native annual forbs, and exotic annual grasses were significantly higher in treated than in untreated areas, with suggestive evidence of more cover by exotic species in treated areas as well. In contrast, cover by herbaceous perennials, native perennial forbs, and exotic annual forbs was significantly lower on treated sites. Native perennial grass cover did not differ between treated and untreated transects.

The proportion of total herbaceous cover comprised of native or exotic species did not differ between treated and untreated transects (Table 2). Perennial species were a larger proportion of the community in untreated than in treated areas, whereas dominance (proportional cover) by annuals, exotic annual grasses, and Vulpia microstachys (Nutt.) Monro, the only native annual grass that occurred in transects, was higher on treated sites. Proportional cover of both exotic annual and native perennial forbs was lower at treated sites, but native annual forbs had $>17 \%$ more proportional cover in treated areas. The proportion of herbaceous cover composed of native perennial grasses did not differ between treated and untreated transects.

Native species diversity and richness did not differ between treated and untreated sites (Table 2). Regeneration of $A$. viscida and C. cuneatus was significantly greater in treated than in untreated sites, but the absolute difference was small $\left(<1.4\right.$ additional stems $\cdot 3 \mathrm{~m}^{-2}$ at treated sites $)$. Regeneration of oak or conifers did not differ significantly between treated and untreated sites (Table 2).

\section{Response Differences Between Treatment Types and Among Vegetation Groups}

Several abiotic variables differed between treatment types across all pairs. For ease of communication, hereafter, we use the terms increase and decrease to describe positive and negative within-pair differences (treated minus untreated), respectively, while acknowledging the lack of certainty about the nature of apparent changes that is inherent to retrospective data. HPB sites had increases in burn-scar cover that MM sites lacked, and MM sites had larger increases in wood debris and decreases in litter than did HPB sites (rank-sum tests, all $P<0.05$; Table 3). However, these between-treatment differences in site conditions did not translate into detectable differences in treatment effects on vegetation. Within-pair differences in herbaceous communities between treatments were not statistically significant (MRPP, Table 4). HPB and MM treatments were indistinguishable in within-pair differences in total herbaceous cover, species diversity and richness, vegetation categories or trait groups (as cover or as propor- 
Table 2. Comparison of differences in means between treated and untreated paired transects for key variables, with variable abbreviations given as used in Table 3. $P$ values are from Wilcoxon sign-rank tests of within-pair difference data (treated minus untreated); percentage of cover and stemcount data were $\log _{10}$-transformed before subtraction (see Analysis Methods). Means and standard deviations presented are from raw data and are percentages, except for regeneration variables (stem counts) and measures of species richness and diversity. Significant $P$ values $(<0.05)$ and corresponding means and standard deviations are in bold; italics indicate suggestive $P$ values.

\begin{tabular}{|c|c|c|c|c|c|c|c|}
\hline Variable name (as given in text) & Variable abbreviation & $P$ & Mean difference & Treated mean & Treated SD & Untreated mean & Untreated SD \\
\hline Canopy cover (woody species $\geq 0.3 \mathrm{~m}$ ) & $\%$ Cover & 0.000 & -71.25 & 25.38 & 18.07 & 96.63 & 18.79 \\
\hline Wood debris cover & WoodDebris & 0.000 & 11.56 & 15.76 & 9.35 & 4.20 & 2.27 \\
\hline Burn scar cover & BurnScar & 0.003 & 6.83 & 6.83 & 12.56 & 0.00 & 0.00 \\
\hline Litter cover & Litter & 0.028 & -7.41 & 51.84 & 10.93 & 59.25 & 16.20 \\
\hline Bare soil cover & Soil & 0.056 & -9.18 & 10.84 & 5.82 & 20.03 & 14.43 \\
\hline Total herbaceous cover & Herbsum & 0.000 & 33.61 & 102.90 & 29.15 & 69.27 & 25.51 \\
\hline Species richness & Richness & 0.380 & 0.70 & 28.93 & 5.33 & 28.23 & 7.12 \\
\hline Native species richness & NatRichness & 0.951 & 0.00 & 21.97 & 4.47 & 21.97 & 4.99 \\
\hline Shannon-Weiner diversity & Diversity & 0.622 & -0.06 & 2.56 & 0.29 & 2.62 & 0.34 \\
\hline Native Shannon-Weiner diversity & NatDiversity & 0.139 & -0.13 & 2.30 & 0.30 & 2.43 & 0.33 \\
\hline Native species cover & Native & 0.000 & 27.58 & 74.59 & 22.37 & 47.01 & 15.81 \\
\hline Exotic species cover & Exotic & 0.074 & 6.03 & 28.29 & 21.05 & 22.26 & 15.59 \\
\hline Annual species cover & Annual & 0.000 & 38.76 & 82.42 & 32.74 & 43.66 & 25.09 \\
\hline Perennial species cover & Perennial & 0.016 & -5.14 & 20.47 & 9.37 & 25.61 & 11.26 \\
\hline Exotic annual grass cover & EAG & 0.000 & 11.31 & 19.50 & 18.93 & 8.19 & 8.76 \\
\hline Native perennial grass cover & NPG & 0.165 & 2.36 & 6.51 & 7.15 & 4.15 & 5.79 \\
\hline Exotic annual forb cover & EAF & 0.032 & -5.14 & 8.65 & 6.58 & 13.79 & 12.28 \\
\hline Native annual forb cover & NAF & 0.000 & 27.48 & 46.72 & 22.43 & 19.24 & 12.49 \\
\hline Native perennial forb cover & NPF & 0.028 & -2.26 & 6.18 & 4.07 & 8.43 & 4.76 \\
\hline Proportion of native species & PropNative & 0.181 & 3.53 & 73.66 & 14.35 & 70.13 & 15.43 \\
\hline Proportion of exotic species & PropExotic & 0.435 & -3.53 & 26.34 & 14.35 & 29.87 & 15.43 \\
\hline Proportion of annual species & PropAnnual & 0.000 & 18.14 & 77.47 & 14.17 & 59.33 & 19.59 \\
\hline Proportion of perennial species & PropPerenn & 0.000 & -18.14 & 22.53 & 14.17 & 40.67 & 19.59 \\
\hline Proportion of exotic annual grasses & PropEAG & 0.001 & 6.18 & 17.12 & 13.15 & 10.94 & 11.28 \\
\hline Proportion of native perennial grasses & PropNPG & 0.959 & 1.02 & 7.60 & 9.12 & 6.58 & 8.80 \\
\hline Proportion of exotic annual forbs & PropEAF & 0.000 & -9.31 & 9.10 & 7.02 & 18.41 & 12.28 \\
\hline Proportion of native annual forbs & PropNAF & 0.000 & 17.60 & 44.08 & 16.36 & 26.47 & 13.51 \\
\hline Proportion of native perennial forbs & PropNPF & 0.028 & -8.16 & 6.30 & 4.31 & 14.46 & 9.11 \\
\hline Oak regeneration & OakRegen & 0.073 & -0.39 & 1.73 & 1.89 & 2.13 & 2.04 \\
\hline Conifer regeneration & ConRegen & 0.415 & -0.03 & 0.03 & 0.09 & 0.05 & 0.14 \\
\hline A. viscida and $C$. cuneatus regeneration & ShrubRegen & 0.000 & 1.37 & 1.67 & 2.32 & 0.30 & 0.42 \\
\hline
\end{tabular}

tions), or canopy species regeneration (rank-sum tests, minimum $P>0.14$; Table 3).

Herbaceous community responses to thinning across treatment types differed significantly between $A$. viscida-dominated and C. cuneatus-dominated canopy groups (MRPP tests of within-pair difference data; Table 4). Differences between $C$. cuneatus-dominated and mixed Q. garryana and shrub groups were suggestive, and there was no evidence that responses differed between A. viscida-dominated and mixed Q. garryana and shrub groups. It is difficult, however, to interpret comparisons of responses between canopy vegetation groups because their herbaceous communities differed in the absence of thinning (Table 1).

\section{DISCUSSION}

Fuel-reduction thinning treatments in chaparral and mixed shrub/oak vegetation of southwestern Oregon appeared to have significant impacts on abiotic site conditions, cover, and composition of herbaceous vegetation and regeneration of canopy species, with impacts still apparent 4-7 yr posttreatment. Treatments reduced canopy cover and density of woody species, and increased cover by wood debris or burn pile scars, while exposed litter cover decreased relative to that in untreated areas (possibly due to litter being covered by wood debris or vegetation). These abiotic differences suggest the occurrence of larger fluctuations in soil temperature, changes in soil moisture regimes, and higher light intensities at treated compared with untreated sites and altered conditions for seed availability, dispersal and germination, and plant survival (Keeley and Zedler 1978; Keeley 1992b; Whisenant 1999; Davis et al. 2000). Site differences between treated and untreated areas were associated with differences in plant communities.

The most pronounced herbaceous vegetation response to treatment was the expansion of cover by annual species. This increase and the decrease in cover by perennials did not 
Table 3. Comparison of mean within-pair differences for key variables between mechanical mastication (MM) and hand-cut and pile-burn (HPB) treatments across canopy vegetation groups. $P$ values are from Wilcoxon rank-sum tests of within-pair difference data (treated minus untreated), with percentage of cover and stem-count data $\log _{10}$-transformed before subtraction (see Analysis Methods). Means and standard deviations are from raw data and are percentages, except for regeneration variables (stem counts) and measures of species richness and diversity. Significant $P$ values $(<0.05)$ and corresponding mean differences and standard deviations are in bold. See Table 2 for definitions of the variable abbreviations.

\begin{tabular}{|c|c|c|c|c|c|}
\hline Variable & $P$ & Mean MM difference & Mean MM difference SD & Mean HPB difference & Mean HPB difference SD \\
\hline$\%$ Cover & 0.916 & -69.81 & 23.46 & -73.41 & 25.90 \\
\hline WoodDebris & 0.001 & 16.79 & 7.73 & 3.71 & 4.21 \\
\hline BurnScar & 0.000 & 0.00 & 0.00 & 17.07 & 15.00 \\
\hline Litter & 0.029 & -12.15 & 12.58 & -0.31 & 19.92 \\
\hline Soil & 0.882 & -9.38 & 14.55 & -8.90 & 16.99 \\
\hline Herbsum & 0.386 & 27.39 & 35.87 & 42.95 & 44.56 \\
\hline Richness & 0.382 & -0.22 & 6.59 & 2.08 & 8.14 \\
\hline NatRichness & 0.610 & -0.50 & 4.90 & 0.75 & 5.88 \\
\hline Diversity & 0.363 & -0.08 & 0.37 & -0.02 & 0.49 \\
\hline NatDiversity & 0.597 & -0.14 & 0.37 & -0.12 & 0.48 \\
\hline Native & 0.434 & 27.95 & 26.51 & 27.02 & 23.27 \\
\hline Exotic & 0.434 & -0.57 & 15.02 & 15.93 & 27.38 \\
\hline Annual & 0.719 & 34.53 & 36.21 & 45.10 & 44.48 \\
\hline Perennial & 0.849 & -7.14 & 10.30 & -2.15 & 10.50 \\
\hline EAG & 0.197 & 3.71 & 9.02 & 22.71 & 22.36 \\
\hline$N P G$ & 0.341 & 1.34 & 3.92 & 3.88 & 6.01 \\
\hline EAF & 0.626 & -4.34 & 11.03 & -6.34 & 11.47 \\
\hline NAF & 0.539 & 27.57 & 22.14 & 27.35 & 22.52 \\
\hline NPF & 0.849 & -2.45 & 6.41 & -1.97 & 2.96 \\
\hline PropNative & 0.280 & 5.24 & 11.76 & 0.97 & 10.45 \\
\hline PropExotic & 0.983 & -5.24 & 11.76 & -0.97 & 10.45 \\
\hline PropAnnual & 0.916 & 19.80 & 21.41 & 15.66 & 17.65 \\
\hline PropPerenn & 0.341 & -19.80 & 21.41 & -15.66 & 17.65 \\
\hline PropEAG & 0.280 & 1.45 & 9.82 & 13.27 & 11.05 \\
\hline PropNPG & 0.446 & -0.69 & 5.81 & 3.59 & 8.97 \\
\hline PropEAF & 0.144 & -6.64 & 8.78 & -13.31 & 12.82 \\
\hline PropNAF & 0.983 & 18.89 & 13.44 & 15.68 & 13.02 \\
\hline PropNPF & 0.300 & -7.52 & 11.48 & -9.13 & 8.20 \\
\hline OakRegen & 0.865 & -0.49 & 2.12 & -0.25 & 1.66 \\
\hline ConRegen & 0.332 & 0.00 & 0.15 & -0.07 & 0.18 \\
\hline ShrubRegen & 0.458 & 1.70 & 2.79 & 0.88 & 1.36 \\
\hline
\end{tabular}

constitute a reversal of dominance; annuals had greater cover than perennials at both treated and untreated sites. However, thinning treatments widened the gap between them-mean

Table 4. Multiple-response permutation procedure (MRPP) tests for differences in treatment effects (within-pair differences in herbaceous cover by species) between treatment types and among canopy vegetation groups. Numbers of pairs per group are indicated for each test. Significant $P$ values $(<0.05)$ and corresponding $A$ values of withingroup homogeneity are in bold. See Table 1 for definitions of treatment type and canopy vegetation group abbreviations (HPB, MM, ARC, CEA, and MIX).

\begin{tabular}{lccc}
\hline Group comparison & No. pairs per group & $P$ & $A$ \\
\hline HPB to MM & 12,18 & 0.084 & 0.006 \\
ARC to MIX to CEA & $10,11,9$ & $\mathbf{0 . 0 2 3}$ & $\mathbf{0 . 0 1 3}$ \\
ARC to CEA & 10,9 & $\mathbf{0 . 0 2 5}$ & $\mathbf{0 . 0 1 3}$ \\
ARC to MIX & 10,11 & 0.150 & 0.006 \\
CEA to MIX & 9,11 & 0.072 & 0.012 \\
\hline
\end{tabular}

proportional cover of annuals was $19 \%$ greater than perennials at untreated sites but $55 \%$ greater at treated sites. Among exotic species, composition shifted from forbs to grasses; exotic annual forbs decreased, whereas exotic annual grasses increased after treatment. Among native species, annuals were favored over perennials by treatments. Native annual forbs showed the greatest posttreatment expansion of any functional group, whereas native perennial forbs declined.

This increase in annual species cover and decline in perennial cover fits an expected early postdisturbance response pattern as does the increase in exotic annual grasses (Keeley et al. 1981; Hobbs and Huenneke 1992; Davis et al. 2000). Herbaceous vegetation at treated sites has apparently persisted in an early postdisturbance community composition for 4-7 yr, dominated by native annual forbs and exotic annual grasses. Abundance of annual and exotic species also increased at treated sites during the first $2 \mathrm{yr}$ after HPB and MM thinning in nearby C. cuneatus chaparral (Sikes 2005), consistent with our longer-term findings. 
There are no published studies on medium- or long-term disturbance responses or on herbaceous community composition for chaparral and oak woodland communities of southwestern Oregon with which our results can be compared. Studies of postfire and thinned fuel-break conditions in California chaparral and of invasive species dynamics from shrub and grassland ecosystems of the interior West and Southern and Central California provide the best available comparison. In contrast to our results, annual species in postfire California chaparral peaked during the first $3 \mathrm{yr}$, whereas proportional cover of perennial species increased over time, such that, by the fourth or fifth postfire year, perennial species comprised most of the herbaceous cover (Keeley et al. 1981). Such trends do not appear to have occurred over this timeframe following thinning treatments in our study area. Extreme or repeated disturbances in chaparral can lead to semipermanent degraded states dominated by annuals or exotic grasses (Vogl 1982; Zedler et al. 1983; Fried et al. 2004; Keeley et al. 2005a, 2005b). The herbaceous communities at treated sites in our study area have features in common with this condition.

Shrub cover often regenerates rapidly after fire in California chaparral, with native shrub cover approaching prefire levels after 5 yr (e.g., Keeley et al. 1981). Although we observed more shrub regeneration at treated than at untreated sites, the difference was small. In our 4-7 yr posttreatment period, shrub regeneration typically accounted for $<3 \%$ cover at treated sites, compared with $\sim 50 \%$ cover at most sites by the third postfire year in California chaparral (Keeley et al. 1981). Although low levels of shrub regeneration may be desirable from a fuel management perspective or on sites where shrubs have encroached upon historic grasslands or woodlands, sparse regeneration may lead to ecosystem state change at sites that were historically dominated by chaparral (Stringham et al. 2001; Hosten et al. 2006). In particular, rapid reestablishment of shrub cover in chaparral ecosystems can diminish invasion and dominance by exotic species (Keeley et al. 2005a, 2005b); without such reestablishment, exotic or early successional native species might maintain longer-term dominance.

A. viscida and C. cuneatus are obligate seeders, with seed germination stimulated by fire- and heat-related cues (Keeley 1987; Fried et al. 2004). Neither species resprouts following fire, nor did we observe resprouting after thinning. In the absence of fire-related cues, reproduction of obligate seeding shrub species is greatly reduced or negligible (Keeley 1992a, 1992b), whereas abundant seedling regeneration by Arctostaphylos and Ceanothus species occurs after wildfires in California (Keeley and Zedler 1978; Odion and Davis 2000). Shrub seedlings on treated sites in our study were concentrated at the periphery of burn scars and in areas of intense solar soil heating (P. Hosten and K. Perchemlides, personal observations, July 2005), consistent with observations for C. cuneatus reported by Sikes (2005). Just east of our study area, however, thinned and subsequently burned $A$. viscida sites showed dense shrub regeneration from seed, with $>50 \%$ cover of young shrubs across extensive areas $<8$ yr posttreatment (K. Perchemlides, personal observation, August 2005). These sites were HPB treated, but the pile-burning phase was atypical, closely resembling a high-severity fire (P. Hosten, personal observation, December 1996); this apparently stimulated shrub regeneration. A lack of fire- or heat-related germination cues across most of the ground surface at our treated sites is probably responsible for the paucity of postthinning shrub reestablishment after 4-7 yr, suggesting that MM and HPB thinning treatments do not mimic fire in their effects on plant communities.

Fire-related cues are also important for seed germination in many native forbs associated with shrub and chaparral communities (Keeley et al. 1985; Keeley and Fotheringham 1998; Borchert 1989). In our case, a lack of fire cues probably influenced posttreatment herbaceous communities directly because of altered germination relative to postfire conditions and indirectly because the shrub canopy did not reestablish. Regenerating shrub canopies reduced herbaceous cover and altered herbaceous species composition within a few years after wildfires in California chaparral (Keeley et al. 1981; Fried et al. 2004; Keeley et al. 2005b). The combination of a lack of fireinduced germination, potential loss of soil seed banks because of fire suppression (Borchert 1989), competition from aggressive exotic species (Hobbs and Huenneke 1992), and sparse canopy regeneration might explain the apparent persistence of an early seral community dominated by native annual forbs and exotic annual grasses on the treated sites we studied.

Of particular concern in the vegetation patterns we observed, is the widespread presence of exotic annual grasses at untreated sites and their more than doubling of cover in response to treatments. Eleven exotic annual grass species occurred in our transects, at least nine of which are considered invasive, noxious, or species of concern (Pyke 1999; Sheley and Petroff 1999; Whitson et al. 2004). At many treated sites, invasive annual grasses grew in dense continuous stands across large areas, especially Avena fatua L., Bromus diandrus Roth, Bromus madritensis L., Bromus tectorum L., and Cynosurus echinatus L. For example, B. tectorum had up to $55 \%$ cover on treated transects, with an average cover of $8.6 \%$ across all treated sites, compared with a maximum cover of $8.4 \%$ and mean of $1.2 \%$ on untreated sites.

Thinning activities, ground disturbance, access routes, crews and equipment may have both introduced and assisted the spread of exotic species at treated sites, consistent with observations in other systems (Backer et al. 2004; Merriam et al. 2006). Soil disturbance, reductions in shrub and litter cover, and availability of seed from preexisting populations probably enhanced exotic annual grass success (Hobbs and Hueneke 1992; Merriam et al. 2006). Higher cover by exotics in general, and exotic annual grasses in particular have been reported 1 to $2 \mathrm{yr}$ after MM and HPB thinning treatments in nearby $C$. cuneatus-dominated communities (Sikes 2005) and in California fuel breaks (Merriam et al. 2006), suggesting that exotic invasive species often expand after fuel-reduction treatments.

These invasive species threaten native ecosystems by competing with and displacing native vegetation, and causing changes in fuel profiles that can shift the fire regime outside of the range of tolerance for native species (Whisenant 1990; Hobbs and Hueneke 1992; Keeley 2001; Brooks et al. 2004). Invasive grass domination can have profound impacts on ecosystem processes, habitat, and forage for herbivores (Pyke 1999; Sheley and Petroff 1999; Lambrinos 2000; Seabloom et al. 2003). The thinning treatment-related expansion of exotic annual grasses reported here adds to concerns raised by others 
about potential conflicts between goals focused on fuel reduction and those focused on exotic species control (e.g., Keeley et al. 2005b). It is, however, important to note that thinning treatments appeared to diminish cover and dominance of exotic annual forbs, with potential benefits to native communities.

The positive response of native annual forbs, whose posttreatment abundance increased more than that of any other trait group, was unexpected, given that these are often relatively poor competitors (e.g., Keeley et al. 2005a). These included species of Madia, Clarkia, Cryptantha, Epilobium, Lotus, and Plagiobothrys and members of the Apiaceae (Perchemlides 2006), which typically occurred on adjacent untreated sites with lower cover. On-site seed from preexisting plants and proximity of treated sites to seed sources in adjacent untreated sites may have fostered these species' success; seed availability was an important limitation for such species in semiarid California grasslands that were dominated by exotic species (Seabloom et al. 2003). Seed sources, soil disturbance, and lowered shrub and litter cover probably facilitated expansion of native annual forbs on our treated sites.

In some chaparral communities in our study area, fire suppression may have allowed growth of overly dense and continuous shrub canopies that reduced herbaceous habitat and caused declines in native species abundance and diversity (USDI 1999). Similarly, in some sites that currently support mixed oak and shrub communities, it is likely that, in the absence of fire, shrubs encroached into previously open oak and perennial bunchgrass systems, altering those ecosystems and causing reductions in native perennial grasses (USDI 1999; Hosten et al. 2006). In such communities, it was hoped that thinning treatments might simultaneously decrease fuels and facilitate ecosystem restoration (e.g., USDI 1999, 2004). However, although treatments did increase herbaceous cover and absolute cover of native species collectively, they did not increase the proportion of native species in the community or affect their richness or diversity. This differs from postwildfire dynamics of herbaceous chaparral communities in California, in which richness and cover were positively correlated (Keeley et al. 1981). The increased cover of native species at our sites was driven by increases in native annuals; cover by native perennial forbs, collectively, was lower after treatment. Neither native perennial grasses nor oak regeneration responded positively to treatments within 4-7 yr, and treatments apparently facilitated expansion of invasive annual grasses that can out-compete and exclude native perennial bunchgrasses (Whisenant 1990; Pyke 1999; Sheley and Petroff 1999). The lack of positive responses by perennial species probably has several causes, which may include a lack of fire cues for germination, competition from annuals, altered germination and growth environments, depleted seed banks (or in the case of native perennial bunchgrasses, sparse populations of established plants for vegetative expansion), and for some species, lesseffective seed dispersal mechanisms relative to annual and exotic species.

Thinning treatments in our study area greatly reduced canopy fuels, effectively meeting fuel management goals related to fire control and firefighter safety. However, the substantial increase in fine surface fuels and wood debris suggests that significant fire hazards remain relative to ecological and vegetation management objectives. Alterations to fuel profiles and fire regimes have had profound impacts on ecosystem processes, vegetation structure and composition, habitat, and invasive species success in other ecoregions (Agee 1993; Keeley 2001; Brooks et al. 2004; Fried et al. 2004; Korb et al. 2004). Dense and continuous cover of fine herbaceous fuels (especially from annual grass species) is associated with increased frequency of fire ignitions and rate of spread (Brooks et al. 2004). When fires occur after thinning treatments, their consumption of an abundant surface layer of wood debris can cause severe burn impacts to soils, vegetation, and seed banks (Bond et al. 1990; Odion and Davis 2000). Such impacts are especially a concern for mechanically treated (MM) sites where wood debris cover increased approximately twice as much as at manually treated (HPB) sites. Because it will decay, increased wood debris is considered a relatively short-term risk from a fuel management perspective. However, wood debris created by treatments at our sites had undergone little visible decay over 4-7 yr, indicating a substantial time span of risk.

Follow-up prescribed burns during relatively cool moist seasons might diminish these risks and stimulate germination of C. cuneatus and A. viscida seeds. Although recovery of a shrub canopy may not be desirable from a fuel management perspective, such recovery might decrease exotic species abundance (e.g., Keeley et al. 2005a, 2005b). On the other hand, increased disturbance frequency in already stressed chaparral systems can exacerbate domination by exotic species (Vogl 1982; Zedler et al. 1983; Fried et al. 2004; Keeley et al. $2005 \mathrm{a}, 2005 \mathrm{~b})$. If plant communities at treated sites in our study area are stressed, as indicated by their prolonged annual domination, follow-up prescribed fire might extend, rather than alleviate, their degradation. Long-term study of plant responses to follow-up prescribed fires, and limited implementation of such burns until results are known, seems warranted.

Finally, herbaceous composition differed between canopy vegetation communities in untreated stands, and we provided evidence that these communities may respond to thinning treatments in distinct ways. Treatment prescriptions and thinning methods may need to be selected and adjusted for specific oak and chaparral community types. Descriptions of current landscape distributions of plant communities (Pfaff 2007) and ongoing research into historic vegetation composition and structure will help establish location-specific treatment goals and prescriptions for the range of plant communities in this region of southwestern Oregon.

\section{MANAGEMENT IMPLICATIONS}

Although successful in terms of fuel management goals focused on fire control, changes in vegetation composition and fuel profiles following fuel-reduction thinning treatments raise some ecological concerns. Posttreatment expansion of exotic annual grasses is a concern throughout our study area. For areas where management goals include restoration or conservation of native vegetation, ecological concerns differ depending on current and historic vegetation. For example, on sites that historically supported open oak grasslands but were invaded by shrubs, the lack of positive response, or even decrease in, native perennials coupled with expansion of exotic annual grasses is worrisome. 
Alternatively, on sites of historical chaparral vegetation, the lack of shrub regeneration and persistence of annual forbs and grasses may indicate risk of an ecological state change to degraded, annual dominated systems. Our results suggest some incompatibility between the achievement of restoration or conservation goals and the fuel-reduction treatments that were applied in our study area. Although in many cases fuel-reduction goals are paramount, particularly when human habitations and property are involved, in many other cases, it is desirable for fuel reduction and ecosystem conservation goals to be sought together. In all cases, treatments that do not foster expansion of exotic annual grasses should be sought.

Fuel reduction and ecological restoration goals for thinning treatments should be defined and adjusted for specific vegetation communities and sites to address ecological concerns and allow evaluation of management outcomes. Research focused on describing historic vegetation structure and fire regimes, and impacts of fire suppression and wildfire on these ecosystems, would help provide a basis for establishing ecological treatment goals and for evaluating the likelihood that thinning prescriptions will decrease fire risks while advancing restoration goals (see Keeley et al. 1999; Keeley and Fotheringham 2001; Moritz et al. 2004). Exploration of alternative prescriptions that might diminish the problems of exotic species expansion and domination by annuals while advancing restoration goals is recommended. Prescriptions might include higher levels of canopy retention, prescribed burning, or reduced size and connectivity of thinning units, along with measures to reduce the introduction or spread of invasive species and seeding of native perennials at sites historically dominated by oak grasslands. The use of prescribed fire as a follow-up treatment (e.g., USDI 2002) offers both hope and concern for the recovery of native plant communities. Our results emphasize the need for expanded long-term monitoring of the impacts of fuel-reduction thinning treatments on oak and chaparral ecosystems of southwestern Oregon, including the extent to which responses depend on canopy vegetation community or treatment type. Treatment plans should include provisions for such monitoring and research, including collection of pretreatment data and inclusion of untreated controls that are large enough to represent pretreatment plant communities in associated treatment sites.

\section{ACKNOWLEDGMENTS}

The authors thank Debora Coen for assistance with data collection; Richard Halse and Bruce McCune of Oregon State University for assistance with plant identification and statistical analyses, respectively; Alan Mason and Greg Chandler of the Medford District BLM for information on fuel treatments; and Edward Reilly and Annette Parsons of the Medford District BLM for assistance with mapping and landscape navigation. We thank M. Keith Owens, an anonymous Associate Editor, and two anonymous reviewers for helpful comments on the manuscript.

\section{LITERATURE CITED}

AgEe, J. K. 1993. Fire ecology of Pacific Northwest forests. Washington, DC, USA: Island Press. 237 p.
AgEe, J. K. 1998. The landscape ecology of western forest fire regimes. Northwest Science 72:24-34.

Backer, D. M., S. E. Jensen, and G. R. McPherson. 2004. Impacts of fire-suppression activities on natural communities. Conservation Biology 18:937-946.

Bond, W. J., D. LeRoux, and R. Erbtzen. 1990. Fire intensity and regeneration of myrmeccochoorous Proteaceae. South African Journal of Botany 56:326330.

BorcheRT, M. 1989. Postfire demography of Thermopsis macrophylla H. A. var. angina J. T. Howell (Fabaceae), a rare perennial herb in chaparral. American Midland Naturalist 122:120-132.

Brooks, M. L., C. M. D’Antonio, D. M. Richardson, J. B. Grace, J. E. Kelley, J. M. DiTomaso, R. J. Hobbs, M. Pellant, and D. Pyke. 2004. Effects of invasive alien plants on fire regimes. BioScience 54:677-688.

Coogle, D. [ED.]. 2002. Balancing act: living with fire in the Applegate-Applegate communities' collaborative fire protection strategy. Applegate, OR, USA: The Applegate Partnership. 200 p.

Covington, W. W., P. Z. Fule, M. M. Moore, S. C. Hart, T. W. Kolb, J. N. Mast, S. S. Sackett, and M. R. Wagner. 1997. Restoring ecosystem health in Pinus ponderosa forests of the southwest. Journal of Forestry 95:23-29.

Covington, W. W., And M. M. Moore. 1994. Southwestern ponderosa pine forest structure: changes since Euro-American settlement. Journal of Forestry 92:39-47.

Davis, M. A., J. P. Grime, and K. Thompson. 2000. Fluctuating resources in plant communities: a general theory of invasibility. Journal of Ecology 88:528534.

DetLing, L. E. 1961. The chaparral formation of southwestern Oregon, with considerations of its post-glacial history. Ecology 42:348-357.

Dickinson, K. J. M., AND J. B. KIRKPATRICK. 1987. The short-term effects of clearfelling and slash-burning on the richness, diversity and relative abundance of higher plant species in two types of eucalypt forest on dolerite in Tasmania. Australian Journal of Botany 35:601-616.

Dombeck, M. P., J. E. Williams, and C. A. Wood. 2004. Wildfire policy and public lands: integrating scientific understanding with social concerns across landscapes. Conservation Biology 18:883-889.

Franklin, J., C. Charlotte, and S. J. Rey. 2004. Change over 70 years in a southern California chaparral community related to fire history. Journal of Vegetation Science 15:701-710.

Franklin, J. F., and C. T. Dyrness. 1973. Natural vegetation of Oregon and Washington. Portland, OR, USA: US Department of Agriculture, Forest Service, Pacific Northwest Forest and Range Experiment Station, General Technical Report PNW-8. 417 p.

Fried, J. S., C. L. Bolsinger, and D. Beardsley. 2004. Chaparral in southern and central coastal California in the mid-1990s: area, ownership, condition and change. Portland, OR, USA: US Dept of Agriculture, Forest Service, Pacific Northwest Research Station, Resource Bulletin PNW-RB-240. 86 p.

Gelbard, J. L., And J. Belnap. 2003. Roads as conduits for exotic plant invasions in a semiarid landscape. Conservation Biology 17:420-432.

Heyerdahl, E. K., L. B. Brubaker, and J. K. Agee. 2001. Spatial controls of historical fire regimes: a multiscale example from the interior west, USA. Ecology 82:660-678.

Hickman, J. C. [ed.]. 1993. The Jepson manual: higher plants of California. Berkeley, CA, USA: University of California Press. 1400 p.

HobBs, R. J., AND L. F. Huenneke. 1992. Disturbance, diversity, and invasion: implications for conservation. Conservation Biology 6:324-337.

Hosten, P. E., G. Hickman, F. Lake, F. Lang, and D. Vesely. 2006. Oak woodland and savanna restoration. In: D. Apostol and M. Sinclair [EDS.]. Restoring the Pacific Northwest: the art and science of ecological restoration in Cascadia. Washington, DC, USA: Island Press. p. 87-123.

Kauffman, J. B., and R. E. Martin. 1987. Effects of fire and fire suppression on mortality and mode of reproduction of California black oak (Quercus kelloggii Newb.). In: T. R. Plumb and N. H. Pillsbury [EDs.]. Proceedings of the Symposium on Multiple-Use Management of California's Hardwood Resources. Berkeley, CA, USA: US Dept of Agriculture, Forest Service, Pacific Southwest Forest and Range Experiment Station, General Technical Report PSW-100. p. 122-126. 
Keeley, J. E. 1987. Role of fire in seed germination of woody taxa in California chaparral. Ecology 68:434-443.

KEELEY, J. E. 1992a. Demographic structure of California chaparral in the long-term absence of fire. Journal of Vegetation Science 3:79-90.

KEELEY, J. E. 1992b. Recruitment of seedlings and vegetative sprouts in unburned chaparral. Ecology 73:1194-1208.

KeELEY, J. E. 2001. Fire and invasive species in Mediterranean-climate ecosystems of California. In: K. E. M. Galley and T. P. Wilson [EDs.]. Proceedings of the Invasive Plant Workshop: The Role of Fire in the Control and Spread of Invasive Species; March 18, 2001; San Diego, CA, USA. Tallahassee, FL, USA: Tall Timbers Research Station. p. 81-94.

Keeley, J. E., and C. J. Fotheringham. 1998. Smoke-induced seed germination in California chaparral. Ecology 79:2320-2336.

Keeley, J. E., and C. J. Fotheringham. 2001. History and management of crown-fire ecosystems: a summary and response. Conservation Biology 15:1561-1567.

Keeley, J. E., C. J. Fotheringham, and M. B. Keeley. 2005a. Determinants of postfire recovery and succession in Mediterranean-climate shrublands of California. Ecological Applications 15:1515-1534.

Keeley, J. E., C. J. Fotheringham, and M. Morals. 1999. Reexamining fire suppression impacts on brushland fire regimes. Science 284:1829-1832.

Keeley, J. E., M. B. Keeley, and C. J. Fotheringham. 2005b. Alien plant dynamics following fire in Mediterranean-climate California shrublands. Ecological Applications 15:2109-2125.

Keeley, J. E., B. A. Morton, A. Pedrosa, and P. Trotter. 1985. Role of allelopathy, heat and charred wood in the germination of chaparral herbs and suffrutescents. Journal of Ecology 73:445-458.

Keeley, J. E., and P. H. Zedler. 1978. Reproduction of chaparral shrubs after fire: a comparison of sprouting and seeding strategies. American Midland Naturalist 99:142-161.

Keeley, S. C., J. E. Keeley, S. M. Hutchinson, and A. W. Johnson. 1981. Postfire succession of the herbaceous flora in southern California chaparral. Ecology 62:1608-1621.

Korb, J. E., N. C. Johnson, And W. W. Covington. 2002. Slash pile burning effects on soil biotic and chemical properties and plant establishment: recommendations for amelioration. Restoration Ecology 12:52-62.

Lambrinos, J. G. 2000. The impact of the invasive alien grass Cortaderia jubata (Lemoine) Stapf on an endangered Mediterranean-type shrubland in California. Diversity and Distributions 6:217-231.

McCune, B., And J. B. Grace. 2002. Analysis of ecological communities. Gleneden Beach, OR, USA: MJM Software Design. 300 p.

McCune, B., ANd M. J. MefFord. 1999. PC-ORD: multivariate analysis of ecological data. Gleneden Beach, OR, USA: MJM Software Design. 237 p

Merriam, K. E., J. E. Keeley, and J. L. Beyers. 2006. Fuel breaks affect nonnative species abundance in California plant communities. Ecological Applications 16:515-527.

Mlller, R. F., J. D. Bates, T. J. Svejcar, F. B. Pierson, and L. E. Eddleman. 2005 Biology, ecology and management of western juniper. Corvallis, OR, USA Oregon State University Agricultural Experiment Station, Technical Bulletin 152. $77 \mathrm{p}$.

Minnich, R. A. 1983. Fire mosaics in southern California and northern Baja California. Science 219:1287-1294.

Moritz, M. A., J. E. Keeley, E. A. Johnson, and A. A. Schaffner. 2004. Testing a basic assumption of shrubland fire management: how important is fuel age? Frontiers in Ecology and the Environment 2:67-72.

MuiR, P. S., AND B. McCune. 1987. Index construction for foliar symptoms of air pollution injury. Plant Disease 71:558-565.

Odion, D. C., and F. W. Davis. 2000. Fire, soil heating, and the formation of vegetation patterns in chaparral. Ecological Monographs 70:149-169.

Odion, D. C., E. J. Frost, J. R. Strittholt, H. Jiang, D. A. Dellasala, and M. A. Moritz. 2004. Patterns of fire severity and forest conditions in the western Klamath Mountains, California. Conservation Biology 18:927-936.

OfFICE OF The President. 2002. Healthy forests: an initiative for wildfire prevention and stronger communities. Washington, DC: Office of the President. Available at: http://www.healthyforests.gov/initiative/. Accessed 29 May 2006.
Perchemlides, K. A. 2006. Impacts of fuel-reduction thinning treatments on oak and chaparral communities of southwestern Oregon [thesis]. Corvallis, OR, USA: Oregon State University. $48 \mathrm{p}$.

Pfaff, E. 2007. Patterns of grassland, shrubland, and woodland vegetation abundance in relation to landscape-scale environmental and disturbance variables, Applegate Watershed, southwest Oregon [thesis]. Ashland, OR, USA: Southern Oregon University. $81 \mathrm{p}$.

Pyke, D. A. 1999. Invasive exotic plants in sagebrush ecosystems of the intermountain west. In: P. G. Entwistle [ED.]. Proceedings of the Sagebrush Steppe Ecosystem Symposium; 21-23 June 1999; Boise, ID, USA. Boise, ID, USA: BLM, Publication BLM/ID/PT-001.001+1150. p. 43-48.

Reed, L. J., and N. G. Sugihara. 1987. Northern oak woodlands-ecosystem in jeopardy or is it already too late? In: T. R. Plumb and N. H. Pillsbury [EDS.]. Proceedings of the Symposium on Multiple-Use Management of California's Hardwood Resources. Berkeley, CA, USA: US Department of Agriculture, Forest Service, Pacific Southwest Forest and Range Experiment Station, General Technical Report PSW-100. p. 59-63.

Seabloom, E. W., E. T. Borer, V. L. Boucher, R. S. Burton, K. L. Cottingham, L. G. Goldwasser, W. K. Gram, B. E. Kendall, and F. Micheli. 2003. Competition, seed limitation, disturbance, and reestablishment of California native annual forbs. Ecological Applications 13:575-592.

Sheley, R. L., and J. K. Petroff [eds.]. 1999. Biology and management of noxious rangeland weeds. Corvallis, OR, USA: Oregon State University Press. $438 \mathrm{p}$.

SIKES, K. G. 2005. The effects of two fuel reduction treatments on chaparral communities in southwestern Oregon [thesis]. Corvallis, OR, USA: Oregon State University. $92 \mathrm{p}$.

Stringham, T. K., W. C. Krueger, and P. L. Shaver. 2001. State and transition modeling, an ecological process approach. Journal of Rangeland Management $56: 106-113$

Swetnam, T. W., C. D. Allen, and J. L. Betancourt. 1999. Applied historical ecology: using the past to manage for the future. Ecological Applications 9:1189-1206.

TAYLoR, A. H., AND C. N. Skinner. 2003. Spatial patterns and controls on historical fire regimes and forest structure in the Klamath Mountains. Ecological Applications 13:704-719.

US Department of Agriculture. 2000. National fire plan: managing the impact of wildfires on communities and the environment. Washington, DC, USA: US Department of Agriculture. Available at: http://www.fireplan.gov/. Accessed 29 May 2006.

[USDI] US Department OF THE Interior. 1999. Ecosystem restoration in the Ashland Resource Area. Medford, OR, USA: USDI Bureau of Land Management, Medford District. $12 \mathrm{p}$.

[USDI] US Department OF The InTERIOR. 2002. Medford District's fire management program 2001/2002. Medford, OR, USA: USDI Bureau of Land Management, Medford District. $16 \mathrm{p}$.

[USDI] US Department OF the InterioR. 2004. Categorical exclusion review and decision record for the Little Applegate fuel hazard reduction project. Medford, OR, USA: USDI Bureau of Land Management, Medford District, Ashland Resource Area. $13 \mathrm{p}$.

[USDI] US Department of The Interior. 2005. Medford District Bureau of Land Management fuels treatment spatial dataset, 1996 through 2005. Maintained by: Medford District GIS staff, A. Parsons. Medford, OR, USA: USDI Bureau of Land Management, Medford District.

Vogl, R. 1982. Chaparral succession. In: C. E. Conrad and W. C. Oechel [eds.]. Proceedings of the Symposium on Dynamics and Management of Mediterranean-Type Ecosystems. Berkeley, CA, USA: US Department of Agriculture, Forest Service, Pacific Southwest Forest and Range Experiment Station, General Technical Report PSW-58. p. 81-85.

Western Regional Climate Center. 2006. Individual weather station historical summary for Ruch, Oregon. Available at: http://www.wrcc.dri.edu/summary/. Accessed 18 April 2006

Whisenant, S. G. 1990. Changing fire frequencies on Idaho's Snake River plains: ecological and management implications. Logan, UT, USA: US Department of Agriculture, Forest Service, Intermountain Research Center, General Technical Report INT-276. 97 p. 
Whisenant, S. G. 1999. Repairing damaged wildlands: a process-oriented, landscape-scale approach. Cambridge, United Kingdom: Cambridge University Press. 312 p.

Whitson, T. D., D. Cudney, and R. Parker [eds.]. 2004. Weeds of the west. 9th ed. Newark, CA, USA: Western Society; and Jackson, WY, USA: University of Wyoming. $628 \mathrm{p}$.
Zedler, P. H., C. R. Gautier, and G. S. McMaster. 1983. Vegetation change in response to extreme events: the effect of a short interval between fires in California chaparral and coastal scrub. Ecology 64:809-818.

Zimmerman, G. M., H. Goetz, and P. W. Mielke, JR. 1985. Use of an improved statistical method for group comparisons to study effects of prairie fires. Ecology 66:606-611. 